\title{
The plasma proteomic signature as a strategic tool for early diagnosis of acute coronary syndrome
}

\author{
Carlos M Laborde', Sergio Alonso-Orgaz¹, Laura Mourino-Alvarez', José Moreu², Fernando Vivanco 3,4, \\ Luis R Padial ${ }^{5}$ and María G Barderas ${ }^{1 *}$
}

\begin{abstract}
Background: Acute coronary syndrome is the major cause of death in developed countries. Despite its high prevalence, there is still a strong need for new biomarkers which permit faster and more accurate diagnostics and new therapeutic drugs. The basis for this challenge lay in improving our understanding of the whole atherosclerotic process from atherogenesis to atherothrombosis. In this study, we conducted two different proteomic analyses of peripheral blood plasma from non-ST elevation acute coronary syndrome and ST elevation acute coronary syndrome patients vs healthy controls.
\end{abstract}

Results: Two-dimensional Fluorescence Difference in Gel Electrophoresis and mass spectrometry permitted the identification of 31 proteins with statistical differences $(p<0.05)$ between experimental groups. Additionally, validation by Western blot and Selected Reaction Monitoring permitted us to confirm the identification of a different and characteristic plasma proteomic signature for NSTEACS and STEACS patients.

Conclusions: We purpose the severity of hypoxia as the cornerstone for explaining the differences observed between both groups.

Keywords: Acute coronary syndrome, Protein, Biomarker, Two-dimensional fluorescence difference in gel electrophoresis

\section{Background}

Acute coronary syndromes (ACS) remains the leading cause of death in developed countries and presents an increasing prevalence in developing countries [1]. Despite its high prevalence, there is currently no biomarker to detect the degenerative process that causes the ACS before their clinical manifestation to appear.

In the last two decades there have been major advances in understanding the pathophysiology of atherogenesis, especially through a better knowledge of the role that inflammation plays in the different stages of plaque development.

Currently, an increasing importance is assumed to the study of the biology and activity of the atherosclerotic plaque. Both factors are considered more important to determine whether a lesion is going to produce an ACS rather than the degree of luminal stenosis [2]. It has been found that biologically active lesions have several

\footnotetext{
* Correspondence: megonzalezb@sescam.jccm.es

'Laboratory of Vascular Physiopathology, Hospital Nacional de Parapléjicos, SESCAM, Toledo, Spain

Full list of author information is available at the end of the article
}

characteristics that distinguish them from the more inactive plaques. These include morphological and inflammatory features, which enhance a large infiltrate of macrophages and lymphocytes, a high production of molecules that destroy the cytoskeleton of the plaque (cytokines, metalloproteinases, etc.) and a decrease in protein synthesis, such as collagen.

It is further known that an adaptive remodelling of the injured artery accompanies the growth of the atherosclerotic plaque. At this stage, the analysis of the coronary lumen does not identify any alteration, while analysis of the arterial wall itself shows its existence. The progressive increase in our knowledge of the intimate relationship between inflammation and atherogenesis has allowed a better understanding of the pathophysiology of this disease $[3,4]$. It has additionally led to the appearance of a large number of studies [5-10], which have discovered potential biomarkers and new therapeutic targets to establish a better and earlier diagnosis of the disease and initiate appropriate treatment to improve the prognosis of patient survival. 
Current clinical criteria for the diagnosis of ACS established by the European Society of Cardiology (ESC) and the American Heart Association (AHA) include the determination of plasma levels of troponin and the heart type creatine kinase isoenzyme (CKMB) [11]. However, in both cases, their plasma levels are not elevated until 4-6 hours after onset of symptoms, which undoubtedly leads a delay in diagnosis.

In this sense, it is necessary the identification of new biomarkers transferable to clinical practice. Its introduction would help to establish an early diagnosis of the disease, could provide new therapeutic targets on which to develop drugs, or could permit monitoring the evolution of patients on a specific treatment and thus to establish a correct prognosis.

In the present study, the objective was to discover whether there was a common protein profile between patients who have suffered a non-ST segment elevation acute coronary syndrome (NSTEACS) and patients who have suffered a ST segment elevation acute coronary syndrome (STEACS) or whether the greater hypoxia at which the myocardium is subjected in the second case and consequently the greater extent of tissue necrosis produced the existence of a characteristic proteomic profile.

\section{Why could be hypoxia important in ACS proteome?}

Biochemical disorders that occur in ischemic heart disease are consequence of hypoxia. Under restricted oxygen conditions, the muscular cells of the myocardium obtain energy from anaerobic glycolysis, resulting in lactate accumulation. This excess of lactate causes an intracellular acidosis that leads to the activation of proteolytic enzymes, to degradation of structural proteins responsible for cardiac contractility, to the loss of integrity of the cell membrane and, ultimately, to the release of proteins to the blood and to the intercellular gap due to cell death.

In this process, the proteins that first appear in the circulation are cytoplasmic (myoglobin and cytoplasmic creatine kinase), followed by mitochondrial proteins (mitochondrial creatine kinase) and structural proteins (troponins and myosin). This explains why different plasma levels of these current clinical biomarkers permit the clinicians to theoretically classify the extension of an ACS.

\section{Results}

The Differential In-gel Analysis (DIA) module detected 1293 and 1884 protein spots in the Two-dimensional Fluorescence Difference in Gel Electrophoresis (2DDIGE) analysis of NSTEACS patients $v s$ healthy controls and STEACS patients vs healthy controls, respectively. Statistical analysis revealed significant alterations in the abundance of 47 protein spots $(p<0.05,13$ upregulated and 34 downregulated, Table 1) and 24 protein spots $(p<0.05,13$ upregulated and 11 downregulated, Table 2), respectively.

These differentially expressed spots were excised from silver stained gels, digested with trypsin and analyzed by MALDI-TOF/TOF. The ensuing database search identified 23 differentially expressed proteins in NSTEACS patients $v s$ healthy controls and 11 in STEACS patients $v s$ healthy controls. The spot maps of both analyses are shown in Figure 1 and complete data of identified spots are shown in Tables 1 and 2 .

Principal component analysis (PCA) was used to reduce the complexity of the multidimensional dataset, providing a clearer overview to better reveal trends within the data. In both 2D-DIGE analyses, this analysis efficiently discriminated NSTEACS (Figure 2A) or STEACS patients (Figure 2B) from healthy controls plasma samples with perfect separation of samples by the first principal component (PC1). In this plot, healthy controls plasma samples were scattered on the left side of the plot and NSTEACS or STEACS plasma samples were located on the right.

The majority of proteins identified in both 2D-DIGE analyses could be classified into seven functional categories (Figure 3), namely: Metabolism ( 3.2\%), Lipid Metabolism and Transport ( 29.3\%), Inflammation and Immune response ( 25.8\%), Blood homeostasis and coagulation ( 16.2\%); Proteases and protease inhibitors ( 9.7\%), Others ( $\sim 6.4 \%)$ and Unknown $(\sim 6.4 \%)$. These functional categories were mainly determined using the Uniprot database:

1. Metabolism: Carbonic anhydrase.

2. Lipid metabolism and transport: ceruloplasmin, apolipoprotein A-IV, vitamin D binding protein, apolipoprotein $\mathrm{E}$, apolipoprotein $\mathrm{AI}$, retinol binding protein 4 and hemopexin.

3. Inflammation and immune response: vitronectin, ficolin 3, inter-alpha-trypsin inhibitor heavy chain $\mathrm{H} 1$, inter-alpha-trypsin inhibitor heavy chain $\mathrm{H} 2$, inter- alpha-trypsin inhibitor heavy chain $\mathrm{H} 4$, complement C1r, alpha-1-antichymotrypsin, kininogen-1, complement factor $\mathrm{H}$, complement factor $\mathrm{H}$ related protein-1 and fibronectin.

4. Blood coagulation and homeostasis: antithrombin III, gamma fibrinogen, heparin cofactor 2, alpha-2macrogobulin and beta-2-glicoprotein 1 .

5. Proteinase inhibitors and proteases: beta-Ala-His dipeptidase, carboxypeptidase $\mathrm{N}$ catalytic chain and kallistatin.

6. Others: haptoglobin and peroxiredoxin 2.

7. Unknown: alpha-1B-glicoprotein and leucine-rich alpha-2-glycoprotein.

\section{Annotation and functional enrichment}

Functional analysis of the altered proteins was performed using DAVID v6.7. Molecular functions and biological 
Table 1 List of identified proteins in the 2D-DIGE analysis of NSTEACS patients vs healthy controls

\begin{tabular}{|c|c|c|c|c|c|c|c|c|c|}
\hline Spot & Protein & $\begin{array}{c}\text { Accession } \\
\text { number }\end{array}$ & $\begin{array}{l}\text { Mascot } \\
\text { score }\end{array}$ & $\begin{array}{c}\text { Ratio } \\
\text { P/C }\end{array}$ & $\begin{array}{c}\text { Theoretical } \\
\text { MW (Da) }\end{array}$ & $\begin{array}{c}\text { Theoretical } \\
\text { PI }\end{array}$ & $\begin{array}{c}\text { Exp MW } \\
(\mathrm{Da})\end{array}$ & $\begin{array}{c}\text { Exp } \\
\text { PI }\end{array}$ & $\begin{array}{l}\text { Biological } \\
\text { function }\end{array}$ \\
\hline 1 & Inter-alpha-trypsin inhibitor heavy chain $\mathrm{H} 4$ & ITIH4_HUMAN & 143 & 1.68 & 103357.43 & 6.51 & 65501 & 4.98 & Inflammation \\
\hline 2 & Inter-alpha-trypsin inhibitor heavy chain $\mathrm{H} 4$ & ITIH4_HUMAN & 91 & 1.76 & 103357.43 & 6.51 & 65295 & 5.01 & Inflammation \\
\hline 3 & Inter-alpha-trypsin inhibitor heavy chain $\mathrm{H} 4$ & ITIH4_HUMAN & 81 & 1.51 & 103357.43 & 6.51 & 65226 & 5.03 & Inflammation \\
\hline 4 & Inter-alpha-trypsin inhibitor heavy chain $\mathrm{H} 4$ & ITIH4_HUMAN & 169 & 1.71 & 103357.43 & 6.51 & 65158 & 5.12 & Inflammation \\
\hline 5 & Ceruloplasmin & CERU_HUMAN & 100 & 1.52 & 122205.19 & 5.44 & 64849 & 5.18 & Transport \\
\hline 6 & Ceruloplasmin & CERU_HUMAN & 163 & 1.56 & 122205.19 & 5.44 & 67216 & 5.34 & Transport \\
\hline 7 & Complement factor $\mathrm{H}$ & CFAH_HUMAN & 102 & -1.69 & 137052.59 & 6.12 & 66942 & 5.45 & Immunity \\
\hline 8 & Complement factor $\mathrm{H}$ & CFAH_HUMAN & 171 & -1.53 & 137052.59 & 6.12 & 67045 & 5.47 & Immunity \\
\hline 9 & Complement factor $\mathrm{H}$ & CFAH_HUMAN & 242 & -1.63 & 137052.59 & 6.12 & 67113 & 5.49 & Immunity \\
\hline 10 & Complement $\mathrm{C} 1 \mathrm{r}$ subcomponent & C1R_HUMAN & 225 & 1.59 & 78213.16 & 5.76 & 60663 & 5.38 & Inflammation \\
\hline 11 & Alpha-1-antichymotrypsin & AACT_HUMAN & 104 & 3.16 & 47650.87 & 5.33 & 55105 & 4.94 & Inflammation \\
\hline 11 & Kininogen-1 & KNG1_HUMAN & 450 & 3.16 & 69896.70 & 6.23 & 55105 & 4.94 & Inflammation \\
\hline 12 & Antithrombin-III & ANT3_PONAB & 150 & 2.86 & 49039.14 & 5.95 & 54556 & 5.27 & Coagulation \\
\hline 13 & Inter-alpha-trypsin inhibitor heavy chain $\mathrm{H} 4$ & ITIH4_HUMAN & 165 & -1.81 & 103357.43 & 6.51 & 51674 & 5.50 & Inflammation \\
\hline 14 & Beta-Ala-His dispeptidase & CNDP1_HUMAN & 431 & 1.53 & 56692.06 & 5.14 & 56477 & 4.68 & Proteolysis \\
\hline 14 & Vitronectin & VTNC_HUMAN & 221 & 1.53 & 54305.59 & 5.55 & 56477 & 4.68 & Inflammation \\
\hline 14 & Alpha-1-antichymotrypsin & AACT_HUMAN & 131 & 1.53 & 47650.87 & 5.33 & 56477 & 4.68 & Inflammation \\
\hline 15 & Gamma fibrinogen & FIBG_HUMAN & 182 & -2.21 & 48483.03 & 5.24 & 49821 & 5.07 & Coagulation \\
\hline 16 & Ceruloplasmin & CERU_HUMAN & 173 & -2.63 & 122205.19 & 5.44 & 45841 & 5.09 & Transport \\
\hline 16 & Apolipoprotein A-IV & APOA4_HUMAN & 121 & -2.63 & 45399.06 & 5.28 & 45841 & 5.09 & Transport \\
\hline 17 & Vitamin D binding protein & VTDB_HUMAN & 163 & -1.88 & 52963.65 & 5.40 & 47522 & 5.17 & Transport \\
\hline 18 & Hemopexin & HEMO_HUMAN & 140 & -2.37 & 51676.37 & 6.55 & 44297 & 5.42 & Transport \\
\hline 19 & Complement factor $\mathrm{H}$ related protein-1 & FHR1_HUMAN & 188 & -3.19 & 35738.20 & 7.10 & 44400 & 5.56 & Inflammation \\
\hline 20 & Catalytic chain carboxypeptidase $\mathrm{N}$ & CBPN_HUMAN & 228 & -1.58 & 50034.39 & 6.88 & 44743 & 6.19 & Peptidase \\
\hline 21 & Leucin rich alpha-2-glicoprotein & A2GL_HUMAN & 143 & -2.01 & 34346.41 & 5.66 & 45326 & 4.47 & Unknown \\
\hline 22 & Kininogen-1 & KNG1_HUMAN & 79 & -1.71 & 69896.70 & 6.23 & 40969 & 4.53 & Inflammation \\
\hline 23 & Heparin cofactor 2 & HEP2_HUMAN & 103 & -1.51 & 54960.02 & 6.26 & 36234 & 4.64 & Coagulation \\
\hline 24 & Complement $\mathrm{C} 1 \mathrm{r}$ subcomponent & C1R_HUMAN & 105 & -1.75 & 78213.16 & 5.76 & 35445 & 5.13 & Inflammation \\
\hline 25 & Apolipoprotein E & APOE_HUMAN & 87 & -1.80 & 34236.68 & 5.52 & 35960 & 5.38 & Transport \\
\hline 26 & Ficolin-3 & FCN3_HUMAN & 127 & -1.83 & 32902.98 & 6.22 & 36612 & 5.68 & Inflammation \\
\hline 27 & Complement factor $\mathrm{H}$ & CFAH_HUMAN & 199 & -1.93 & 137052.59 & 6.12 & 36509 & 5.83 & Inflammation \\
\hline 28 & Complement factor $\mathrm{H}$ & CFAH_HUMAN & 169 & -1.78 & 137052.59 & 6.12 & 36268 & 5.99 & Inflammation \\
\hline 29 & Antithrombin-III & ANT3_HUMAN & 138 & -2.08 & 49039.14 & 5.95 & 21652 & 5.18 & Coagulation \\
\hline 30 & Apolipoprotein A-I & APOA1_HUMAN & 101 & -2.68 & 28078.62 & 5.27 & 23333 & 5.48 & Transport \\
\hline 31 & Retinol binding protein 4 & RET4_HUMAN & 80 & -1.52 & 21071.60 & 5.27 & 17844 & 5.61 & Transport \\
\hline 32 & Kininogen-1 & KNG1_HUMAN & 142 & -2.37 & 69896.70 & 6.23 & 13452 & $4.68-$ & Inflammation \\
\hline 33 & Kininogen-1 & KNG1_HUMAN & 143 & -2.37 & 69896.70 & 6.23 & 11016 & 4.82 & Inflammation \\
\hline 34 & Apolipoprotein A-IV & APOA4_HUMAN & 204 & -2.97 & 45399.06 & 5.28 & 7173 & 4.74 & Transport \\
\hline 35 & Fibronectin & FINC_HUMAN & 185 & 1.66 & 259562.86 & 5.40 & 55654 & 5.98 & Inflammation \\
\hline 35 & Alpha-2-macroglobulin & A2MG_HUMAN & 174 & 1.66 & 160809.88 & 5.98 & 55654 & 5.98 & Coagulation \\
\hline
\end{tabular}

PI: isoelectric point; MW: molecular weight; Prot score: score in MASCOT; Ratio P/C: variation between the patient group and the control group. 
Table 2 List of identified proteins in the 2D-DIGE analysis of STEACS patients vs healthy controls

\begin{tabular}{|c|c|c|c|c|c|c|c|c|c|}
\hline Spot & Protein & $\begin{array}{c}\text { Accession } \\
\text { number }\end{array}$ & $\begin{array}{c}\text { Mascot } \\
\text { score }\end{array}$ & $\begin{array}{c}\text { Ratio } \\
\text { P/C }\end{array}$ & $\begin{array}{l}\text { Theoretical } \\
\text { MW (Da) }\end{array}$ & $\begin{array}{c}\text { Theoretical } \\
\text { PI }\end{array}$ & $\begin{array}{c}\text { Exp MW } \\
\text { (Da) }\end{array}$ & $\begin{array}{c}\text { Exp } \\
\text { PI }\end{array}$ & $\begin{array}{l}\text { Biological } \\
\text { function }\end{array}$ \\
\hline 1 & Inter-alpha-trypsin inhibitor heavy chain $\mathrm{H} 2$ & ITIH2_HUMAN & 143 & 1.58 & 72452.28 & 5.75 & 105156 & 4.61 & Inflammation \\
\hline 2 & Inter-alpha-trypsin inhibitor heavy chain $\mathrm{H} 2$ & ITIH2_HUMAN & 91 & 1.74 & 72452.28 & 5.75 & 104880 & 4.62 & Inflammation \\
\hline 3 & Inter-alpha-trypsin inhibitor heavy chain $\mathrm{H} 2$ & ITIH2_HUMAN & 81 & 1.76 & 72452.28 & 5.75 & 104605 & 4.70 & Inflammation \\
\hline 4 & Inter-alpha-trypsin inhibitor heavy chain $\mathrm{H} 2$ & ITIH2_HUMAN & 127 & 1.56 & 72452.28 & 5.75 & 104605 & 4.72 & Inflammation \\
\hline 5 & Inter-alpha-trypsin inhibitor heavy chain $\mathrm{H} 2$ & ITIH2_HUMAN & 169 & 1.87 & 72452.28 & 5.75 & 104605 & 4.64 & Inflammation \\
\hline 6 & Inter-alpha-trypsin inhibitor heavy chain $\mathrm{H} 2$ & ITIH2_HUMAN & 162 & 2.01 & 72452.28 & 5.75 & 104743 & 4.67 & lation \\
\hline 7 & Inter-alpha-trypsin inhibitor heavy chain $\mathrm{H} 2$ & ITIH2_HUMAN & 114 & 1.97 & 72452.28 & 5.75 & 104468 & 4.69 & Inflammation \\
\hline 8 & Inter-alpha-trypsin inhibitor heavy chain $\mathrm{H} 2$ & TTH2 HUMAN & 126 & 1.51 & 72452.28 & 5.75 & 104468 & 4.74 & Inflammation \\
\hline 9 & Fibronectin & FINC_HUMAN & 181 & -1.90 & 259562.86 & 5.39 & 95790 & 5.35 & Inflammation \\
\hline 10 & Inter-alpha-trypsin inhibitor heavy chain $\mathrm{H} 1$ & ITIH1_HUMAN & 123 & 1.53 & 71415.01 & 6.36 & 89463 & 5.75 & Inflammation \\
\hline 11 & Haptoglobin & HPT_HUMAN & 107 & -2.79 & 43349.01 & 6.13 & 44644 & 5.16 & Homeostasis \\
\hline 12 & Alpha-1B-glicoprotein & A1BG_HUMAN & 218 & -3.64 & 51921.66 & 5.63 & 44003 & 5.30 & Unknown \\
\hline 13 & Hemopexin & HEMO_HUMAN & 467 & -8.90 & 4295.43 & 6.43 & 61518 & 5.92 & Transport \\
\hline 14 & Kallistatin & KAIN_HUMAN & 107 & -2.27 & 46355.24 & 7.88 & 61115 & 5.95 & Protease inhibitor \\
\hline 15 & Beta-2-glicoprotien $1(\mathrm{ApoH})$ & APOH_HUMAN & 80 & -2.80 & 36254.60 & 8.37 & 61035 & 6.09 & Coagulation \\
\hline 16 & Peroxiredoxin-2 & PRDX2_HUMAN & 131 & -4.36 & 21760.73 & 5.67 & 18607 & 5.30 & Anti-apoptosis \\
\hline 17 & Antithrombin III & ANT3_HUMAN & 100 & -4.23 & 49039.14 & 5.95 & 14232 & 5.44 & Coagulation \\
\hline 18 & Carbonic anhydrase & CAH1_HUMAN & 124 & -5.02 & 28739.02 & 6.63 & 25844 & 6.17 & Metabolism \\
\hline
\end{tabular}

PI: isoelectric point; MW: molecular weight; Prot score: score in MASCOT; Ratio P/C: variation between the patient group and the control group.

processes were explored through the functional annotation tool to generate clusters of overrepresented Gene Ontology (GO) terms. Molecular function analysis in NSTEACS showed that a big number of the altered proteins had enzyme inhibitor activity. High fold enrichment was also related to immune response and inflammation. Complement activation, homeostasis and coagulation together with immune response and inflammation are the biological processes more representative in which altered proteins are primarily involved.

Pathway analysis revealed a significant enrichment in Intrinsic Prothrombin Activation Pathways (BIOCARTA) as well as in complement and coagulation cascades (KEGG). In the case of STEACS, pathways analysis did not reveal a significant enrichment.

Functional annotation clustering tool was used to gather molecular function and biological process results. Seven significant clusters were obtained: inflammation and immune response (enrichment score: 5.62), enzyme inhibitor activity (enrichment score: 4.66), metabolism (2.96), response (2.46), regulation (2.36) binding-related (enrichment score: 2'3), and homeostasis (enrichment score: 2.19).

\section{Protein-protein interaction}

The 23 dysregulated proteins determined in the NSTEACS 2D-DIGE experiment were introduced into the web-tool STRING v9.1 to generate protein-protein interactions networks. After clustering, seven functional modules forming tightly connected clusters can be observed (Figure 4A). Regarding STEACS 2D-DIGE experiment, after clustering two functional clusters were observed (Figure 4B).

\section{Validation by Western blot}

To confirm the proteomic results, western blot was performed to antithrombin III $(\sim 49 \mathrm{kDa})$, alpha-1antiquimiotripsin $(\sim 48 \mathrm{kDa})$, hemopexin $(\sim 50 \mathrm{kDa})$, apolipoprotein AI $(\sim 30 \mathrm{kDa})$, gamma fibrinogen $(\sim 48 \mathrm{kDa})$, apolipoprotein $\mathrm{E}(\sim 36 \mathrm{kDa})$, and kallistatin $(\sim 46 \mathrm{kDa})$ using a densitometry software (Quantity One, BioRad). In case of hemopexin and antithrombin III, these proteins were validated in both, NSTEACS and STEACS patients (Figure 5).

\section{NSTEACS patients vs healthy controls}

For antithrombin III, the analysis of band intensity showed a statistically significant decreasing expression in NSTEACS patients compared with healthy controls $(\mathrm{p}=$ 0.036 ). In the $2 \mathrm{D}$ western blot of alpha-1-antichymotrypsin several protein isoforms were observed. The two isoforms that were found differentially expressed in the 2D-DIGE were also increased.

The 2D western blot of apolipoprotein $\mathrm{E}$ and hemopexin confirmed the results obtained in the 2D-DIGE $(-1.80$ and -2.37 , respectively) showing a decreasing expression in NSTEACS patients. Gamma fibrinogen showed several isoforms. The differentially reduced isoform found in the 



Figure 1 Differential protein spots obtained in both 2D-DIGE analyses. (A) NSTEACS vs controls and (B) STEACS vS Controls.

2D-DIGE analysis (-1.58) also showed diminished levels of expression in the patient group NSTEACS. Similar results were obtained with apolipoprotein AI, where 2D western blot confirmed the decreased expression levels in patients with NSTEACS previously observed (-2.68).

\section{STEACS patients vs healthy controls}

The analysis of band intensity for antithrombin III, hemopexin and kallistatin showed, in all three cases, a statistically significant decrease in their expression levels in patients with STEACS versus healthy controls with significance values $\mathrm{p}=0.0066, \mathrm{p}=0.0077$ and $\mathrm{p}=0.005$ respectively, confirming the results obtained in 2D-DIGE.

\section{Validation by Selected Reaction Monitoring (SRM)}

Additionally, in order to complete the validation of the results obtained in the two previous proteomic analyses, several proteins with altered expression profiles detected
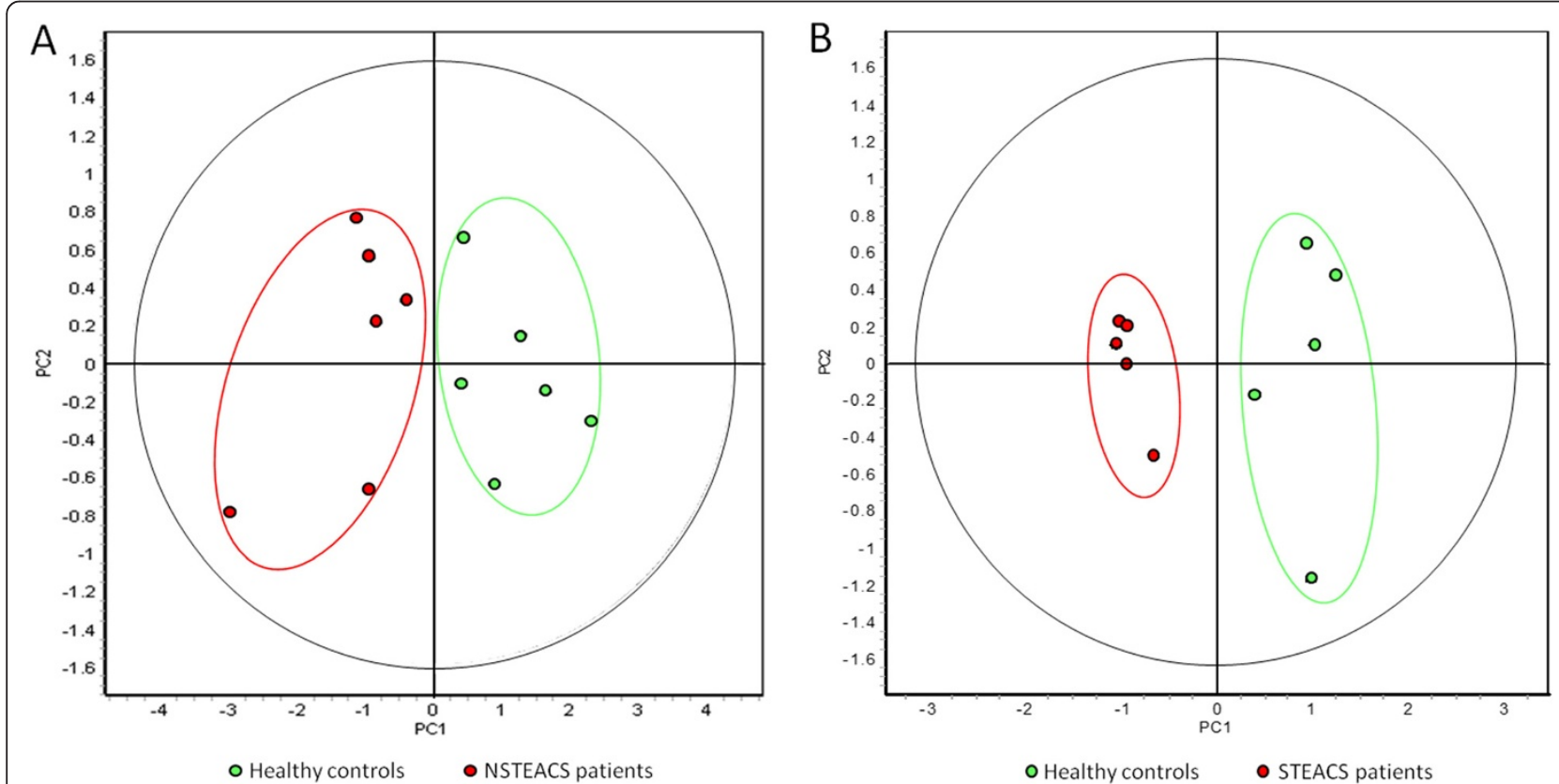

Figure 2 Score plots obtained in the PCA for data from the NSTEACS vs controls (A) and STEACS vs controls (B) 2D-DIGE analyses. 


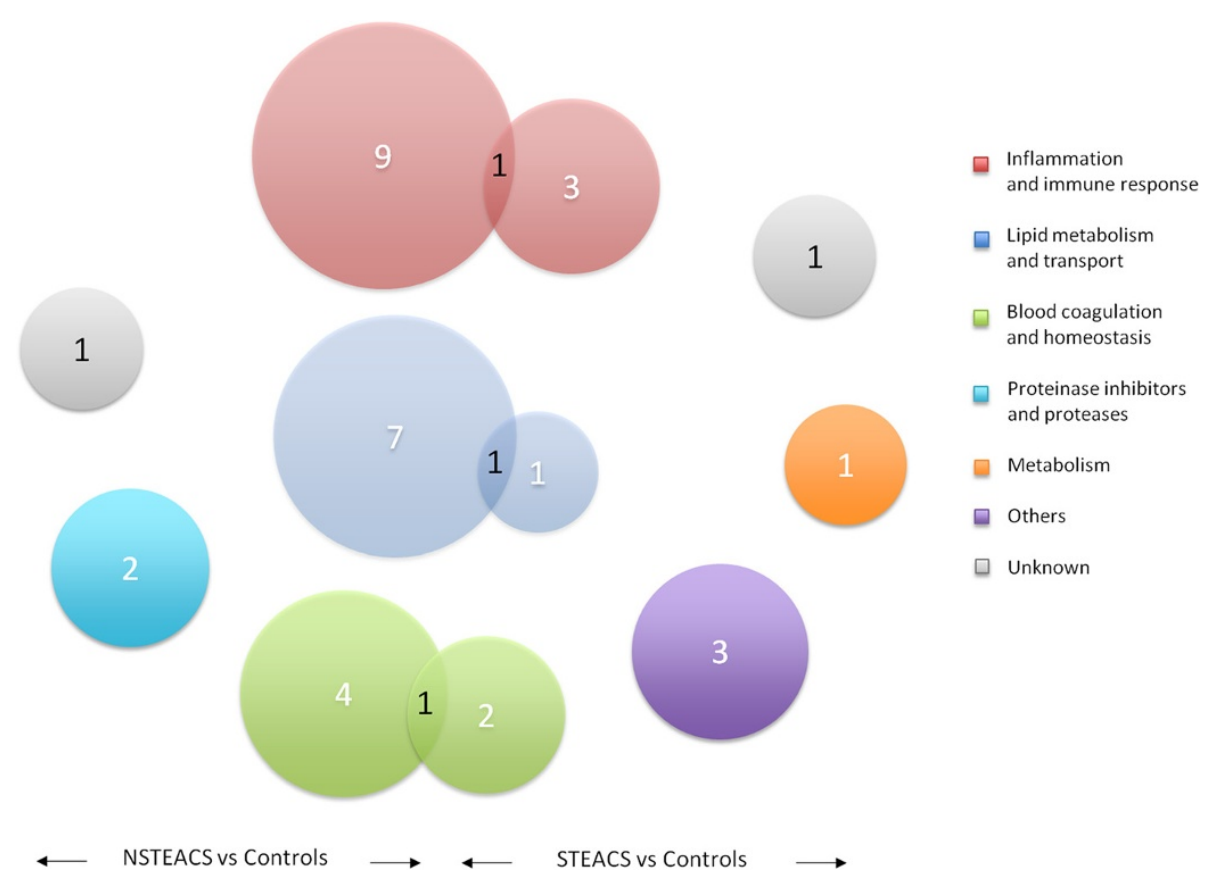

Figure 3 Venn diagram showing the proteins identified in both 2D-DIGE analyses.

in the different 2D-DIGE analyses were monitored by SRM.

\section{NSTEACS patients vs healthy controls}

The proteins ceruloplasmin ( $\mathrm{p}<0.001$ and $\mathrm{p}<0.001)$, inter alpha trypsin inhibitor heavy chain $\mathrm{H} 4(\mathrm{p}=0.019$ and $\mathrm{p}=0.021)$, apolipoprotein $\mathrm{E}(\mathrm{p}=0.0087$ and $\mathrm{p}=0.0147)$, vitamin $\mathrm{D}$ binding protein $(\mathrm{p}=0.0208$ and $\mathrm{p}=0.0237)$ and kininogen-1 $(p=0.0007$ and $p=0.0163)$ showed statistically significant differences in both peptides after statistical analysis using a Student $t$-test $(\mathrm{p}<0.05)$ (Figure 6A).

Hemopexin $(\mathrm{p}=0.0277$ and $\mathrm{p}=0.0591)$ and apolipoprotein A-IV ( $\mathrm{p}=0.0173$ and $\mathrm{p}=0.1518)$ showed significant differences in one of the two monitored peptides. In the case of hemopexin, one of the two peptides was very close to statistical significance $(p=0.0591)$ and since it had been previously validated by western blot this validation by SRM was accepted.

\section{STEACS patients vs healthy controls}

Similarly, an independent group of samples ( $\mathrm{n}=15$ STEACS patients, $\mathrm{n}=15$ healthy controls) was used. Alpha 1B-glycoprotein $(\mathrm{p}=0.0029$ and $\mathrm{p}=0.0139)$, beta2 glycoprotein-1 (apo $\mathrm{H}) \quad(\mathrm{p}=0.0047$ and $\mathrm{p}=0.0213)$, peroxiredoxin $2(\mathrm{p}=0.0003$ and $\mathrm{p}=0.0083)$, antithrombin III ( $\mathrm{p}=0.0111$ and $\mathrm{p}=0.0234)$ and kallistatin $(\mathrm{p}=$ 0.0058 and $\mathrm{p}=0.0179$ ) showed statistically significant differences in both peptides after statistical analysis using Student's $t$-test (Figure 6B). Results obtained for antithrombin III and kallistatin were validated by western blot and SRM.

Globally, the results obtained by these two different validation methods confirmed those obtained from both plasma proteomic analyses using the DIA module.

\section{Discussion}

Because of the current clinical tests for ACS just permits its diagnosis after the onset of the syndrome, the discovery of new biomarkers reflecting the development of the atherosclerotic process results critical.

For studying potential candidates, it is previously necessary to consider the basic characteristic that every clinical biomarker should meet; high sensitivity and high specificity. Sensitivity, in many cases, depends on the technique used and it usually improves with different generations of reagents as it has happened with troponin and ultrasensitive reactive $C$ protein. Specificity, however, is a parameter that must be carefully considered from the outset. In our study, we found a total number of 31 altered proteins. Despite this apparently attractive result, many of these proteins do not offer the previously mentioned characteristic of an ideal biomarker. This happens with vitamin D-binding protein (VDBP) and the family of inter-alpha trypsin inhibitors which have been related to different inflammatory diseases such as rheumatoid arthritis, liver cirrhosis and Crohn's disease $[12,13]$. Since they have been also found altered in a number of pathological states, their lack of specificity prevents its clinical use for diagnosis of ACS. 


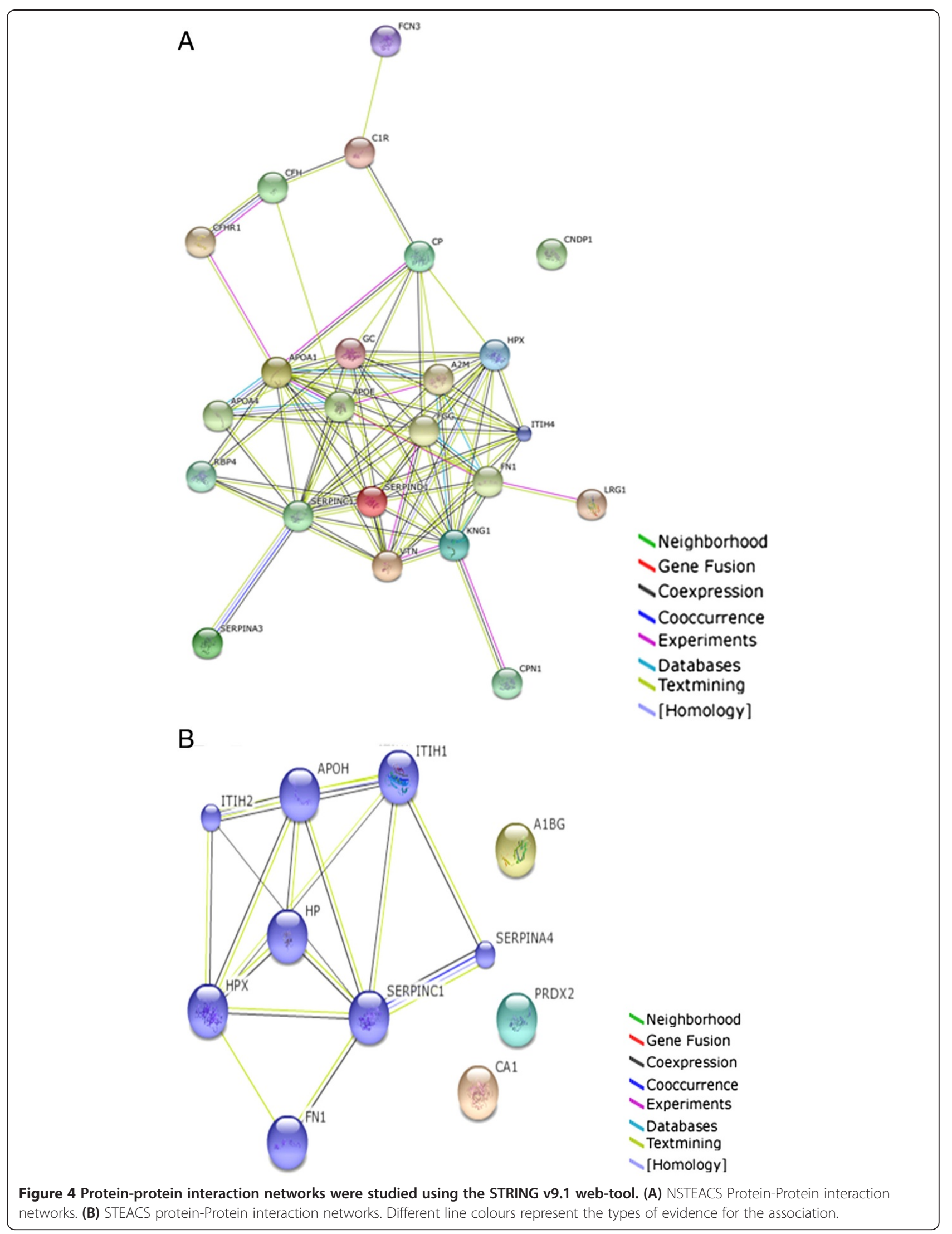




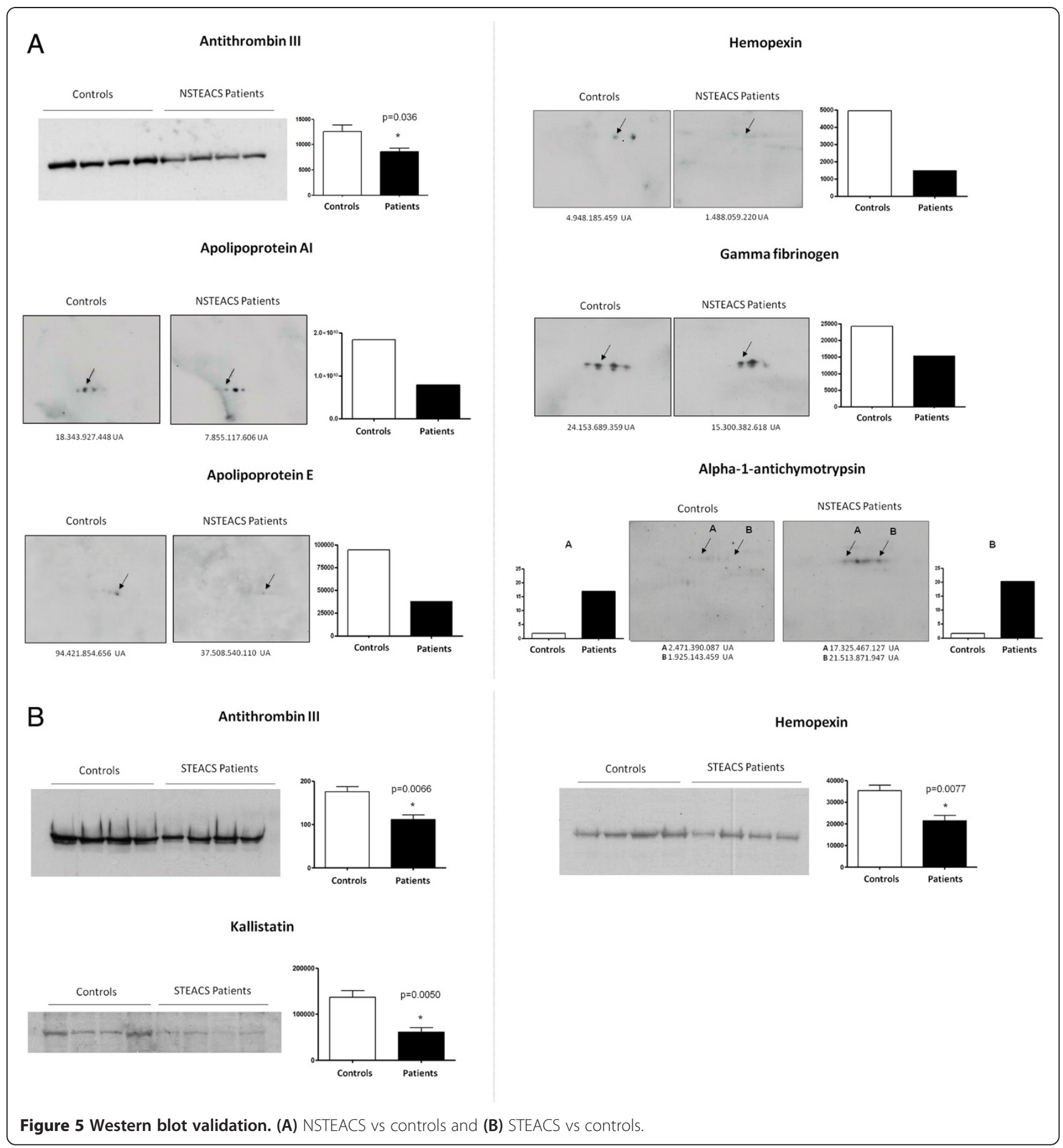

\section{Interesting proteins with potential clinical use}

Fortunately, many of identified proteins are interesting in terms of new biomarkers discovery or better understanding of physiopathology of ACS. In this sense, one of the most remarkable results was the alteration of three proteins with antioxidant properties; haptoglobin, 1B-glycoprotein and peroxiredoxin-2 [14,15]. In all cases, decreased plasma levels were found in STEACS patients. Therefore, we consider that this alteration could trigger the damage caused by reactive oxygen species (ROS) due to the lack of protective antioxidant effect [16-18]. Similarly, decreased levels of ceruloplasmin and hemopexin could produce an increase of free oxygen promoting tissue oxidation during the atherogenic process due to its ability to catalyse the reduction of oxygen molecules [19] and protect against oxidation of the LDL caused by hemoproteins, respectively $[16,17]$. In this group of proteins whose decreased plasma levels may predispose to suffer ACS, we 


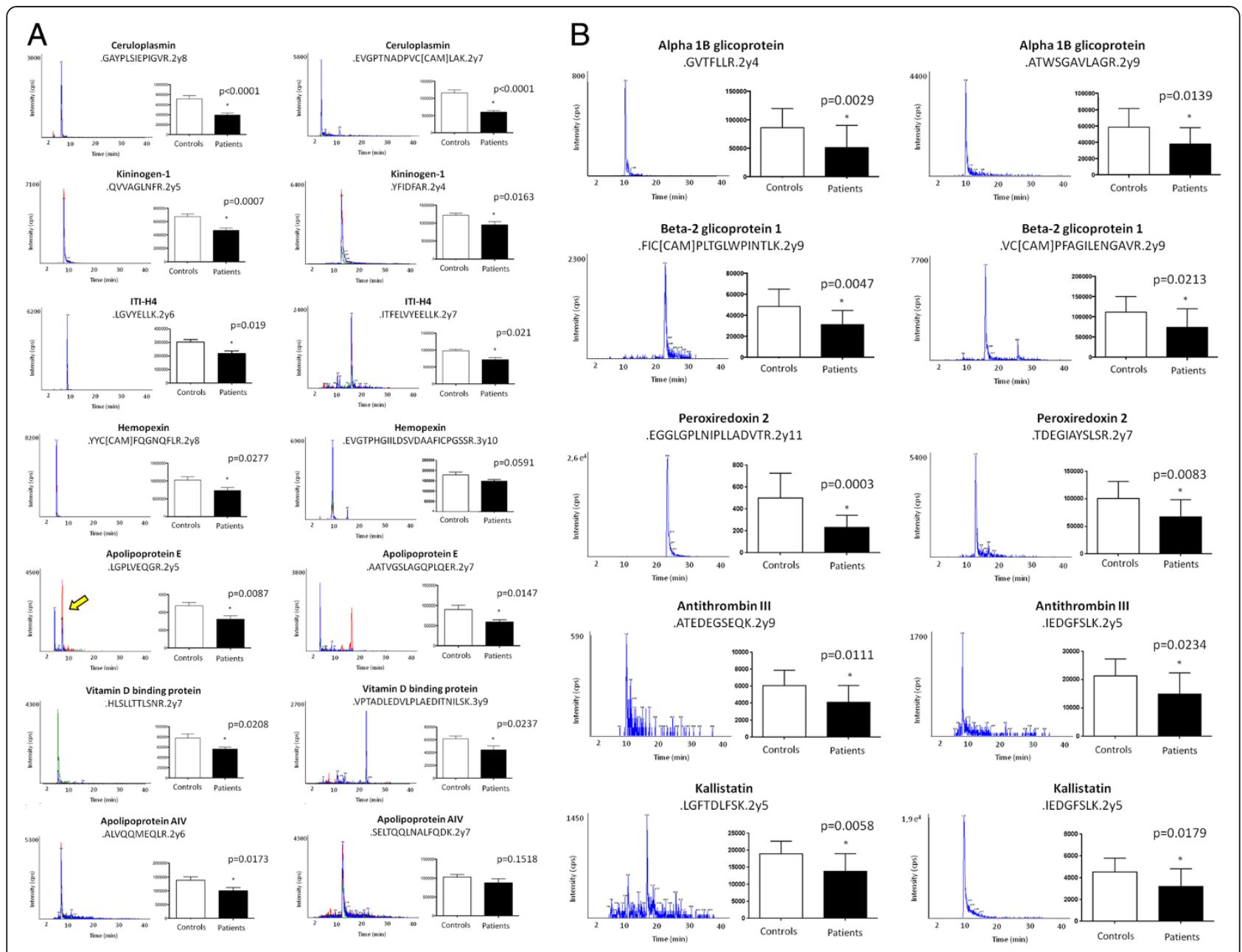

Figure 6 SRM validation. (A) NSTEACS vs controls and (B) STEACS vs controls. The yellow narrow shows the SRM transition of interest.

also include kallistatin, a member of the superfamily of serine protease inhibitors with various effects including powerful vasodilator activity, inhibition of angiogenesis and anti-inflammatory activity [20-22].

Extensively known is the role of apolipoproteins in the metabolism and transport of cholesterol. We found several apolipoproteins; ApoA-I, ApoA-IV, ApoE and ApoH with decreased plasma levels in ACS patients. Due to their biological functions, their alterations could favour the appearance of a pro-thrombotic state and the progression of atherosclerosis [23-27].

Coagulation is a basic phase in ACS onset. Fibrinogen and antithrombin III are currently used in clinical practice for the diagnosis of different coagulation alterations. In this group of proteins we also include kininogen-1, a multifunctional protein that participates in the intrinsic pathway of the coagulation as a part of the kallikreinkinin system $[28,29]$ inhibiting platelet aggregation induced by thrombin and plasmin [30,31]. We hypothesize that decreased plasma levels of kininogen-1 could promote platelet aggregation and trigger the progression of atherosclerosis.

One of the most exciting results that we observed in the STEACS plasma proteome was the alteration of carbonic anhydrase. This protein catalyses the rapid conversion of carbon dioxide and water to bicarbonate and free protons to maintain the acid-base balance in the blood and other tissues. It decreased levels in STEACS patients permits us to postulate that tissue hypoxia carries a cardiac muscle intracellular acidosis situation caused by the production of lactic acid derived from anaerobic glycolysis. This state of acidosis would modify the reaction equilibrium in the opposite direction catalysed by the enzyme to prevent the formation and release of higher acid content in the cells. Since carbonic anhydrase was altered in STEACS but not in NSTEACS patients, its decreased plasma levels may have potential to differentiate the extent of cardiac necrosis in ACS.

In summary, ACS is a multifactorial disease in which several processes contribute to the development of the 
plaque. For this reason, we considered that there is not the possibility of defining a single diagnostic biomarker. In contrast, a panel of biomarkers reflecting these processes could help clinicians to correctly and individually diagnose the risk of every patient of suffering an ACS. In our opinion, this panel should be formed by proteins related to oxidative damage (i.e. hemopexin and ceruloplasmin), coagulation (i.e. kininogen-1 and antithrombin III) and hypoxia (carbonic anhydrase), which were all of them found altered in this study.

\section{Future lines of research}

The results obtained in this study also permits to picture some interesting lines of research for the future. The relationship between different cardiovascular diseases such as ACS and aortic stenosis (AS) could be elucidated through a deeper knowledge of the plasma proteome. In this sense, we obtained statistical differences in two proteins; alpha-1-antichymotrypsin and leucine-rich alpha2 -glycoprotein that we had previously found altered in AS [32]. We believe that these two proteins could play a role in the development of both inflammatory pathologies and permit us to suggest new lines of research to study the possible relationship between AS and atherosclerosis and the differences between these two processes.

\section{Conclusions}

In the present study, our results from both 2D-DIGE analyses permitted us to suggest that NSTEACS patients had a characteristic plasma proteomic profile that differentiates them from those patients who have suffered a STEACS. Although in both 2D-DIGE experiments some patients had previously suffered ACS, as it was explained in detail in the Material and method section any previous disease or surgery should have occurred in a six months period before being included in the study. In our opinion, this period of time is broad enough to consider that the existence of a previous ACS in any patient would have no influence on the protein pattern found in our studies.

Additionally, in spite of the large variety of biological processes of the identified proteins, based on our previous experience in secretome studies, the tissue is the origin of many of them $[33,34]$. As previously explained in the Background section, the wide number of biochemical disorders secondary to hypoxia suffered by the myocardium lead to tissue breakdown and the releasing of a large number of proteins of potential interest into the blood stream. In fact, among the proteins forming the characteristic plasma proteomic profile for STEACS patients appeared decreased expression levels of three proteins with antioxidant activity (1B-glycoprotein, peroxiredoxin-2 and haptoglobin) which will possible catalyze the damage caused by the plasma ROS in the endothelium. In spite of a direct NSTEACS vs STEACS 2D-DIGE would probably confirm these results, we are strongly confident that the global proteome described in this study permit us to suggest the need to consider the use of a panel of biomarkers as the most useful tool for early diagnosis of ACS.

\section{Methods}

\section{Patient selection and sample collection}

The study was conducted according to the Declaration of Helsinki and it was approved by the ethics committee of the Hospital Virgen de la Salud (Toledo). All the patients and controls signed an informed consent before their inclusion in the study.

Three experimental groups were selected: 1) NSTEACS patients, 2) STEACS patients and 3) healthy controls. Blood samples (K3 EDTA) of NSTEACS and STEACS patients and sex and age matched healthy subjects were recruited from the Cardiology Service of Hospital Virgen de la Salud (Toledo, Spain). In case of ACS patients, the samples were obtained in the onset of the syndrome $(t=0 h)$ defined as the moment when the coronary event is diagnosed.

Different pathologies and situations were considered as exclusion criteria. Tumour inflammatory diseases, alterations of coagulation, the existence of significant heart disease unrelated to the disease or its risk factors (valvular, pericardial affectations or cardiomyopathies), chronic treatments, except for ischemic heart disease and its risk

Table 3 Baseline characteristics of healthy controls and ACS patients included in the study

\begin{tabular}{|c|c|c|c|}
\hline & $\begin{array}{l}\text { Healthy } \\
\text { controls } \\
(n=30)\end{array}$ & $\begin{array}{c}\text { NSTEACS } \\
\text { patients } \\
(\mathrm{n}=30)\end{array}$ & $\begin{array}{c}\text { STEACS } \\
\text { patients } \\
(\mathrm{n}=30)\end{array}$ \\
\hline \multicolumn{4}{|l|}{ Personal data } \\
\hline Age (years) $\pm S D$ & $64.2 \pm 11,5$ & $68.3 \pm 9.8$ & $67.1 \pm 8.7$ \\
\hline Sex (Male/Female) & $17 / 18$ & $27 / 8$ & $21 / 6$ \\
\hline \multicolumn{4}{|l|}{ Risk factors } \\
\hline Smokers & 3 & 10 & 9 \\
\hline Ex-smokers & 3 & 8 & 7 \\
\hline Diabetes mellitus & 1 & 5 & 7 \\
\hline Dyslipidemia & 6 & 23 & 17 \\
\hline Hypertension & 14 & 22 & 22 \\
\hline Renal disease & 0 & 3 & 3 \\
\hline \multicolumn{4}{|l|}{ Biochemical data } \\
\hline Total cholesterol (mg/ & $182 \pm 37$ & $165 \pm 27$ & $172 \pm 28$ \\
\hline $\mathrm{LDL}(\mathrm{mg} / \mathrm{dL})$ & $103 \pm 36$ & $99 \pm 28$ & $109 \pm 31$ \\
\hline $\mathrm{HDL}(\mathrm{mg} / \mathrm{dL})$ & $50 \pm 12$ & $49 \pm 8$ & $47 \pm 9$ \\
\hline Triglycerides (mg/dL) & $123 \pm 50$ & $144 \pm 59$ & $161 \pm 43$ \\
\hline \multicolumn{4}{|l|}{ Background data } \\
\hline Previous ACS & $0 \%$ & 8 & 4 \\
\hline Statins & $0 \%$ & 17 & 10 \\
\hline
\end{tabular}


factors, coronary angiograms normal ejection fractions less than 0.45 , major trauma, thromboembolic events, revascularization or having undergone surgery within six months before the start of the study. The control group included 30 healthy volunteers with normal coronary arteries and up to two cardiovascular risk factors who attended the Department of Hemodynamic for various reasons. All healthy volunteers and patients had a sex and age distribution with no significant differences between them (Table 3).

\section{Depletion of high-abundant plasma proteins}

In order to increase the concentration of low-abundant proteins in plasma samples, the 14 most abundant plasma proteins were specifically removed by affinity chromatography using the Multiple Affinity Removal Column (MARS Hu-14, Agilent Technologies). This technique has proven to be an interesting tool in the search for plasma biomarkers $[32,35,36]$.

Depletion was performed by high performance liquid chromatography (HPLC) using a 1200 series HPLC chromatograph (Agilent Technologies) equipped with a manual injector (9725i, Agilent Technologies). After several chromatographic cycles, aliquots of the flow-through fractions containing low-abundance proteins were combined and desalted using centrifugal filter devices with a $3 \mathrm{kDa}$ cut off (Amicon Ultra, Millipore). These samples were stored at $-80^{\circ} \mathrm{C}$ prior to analysis and the protein concentration was determined using the Bradford-Lowry method [37].

\section{Two-dimensional differential in gel electrophoresis (2D-DIGE)}

NSTEACS plasma samples $(n=5)$ and healthy control samples $(n=5)$ or STEACS plasma samples $(n=6)$ and healthy control samples $(n=6)$ with similar clinical parameters were used in both 2D-DIGE analyses. This technique is based on the specific linkage of three fluorochromes with differential spectral properties $(\mathrm{Cy} 2, \mathrm{Cy} 3$ and Cy5). It permits the separation of multiple samples in a single gel increasing the reproducibility and reliability of the analysis of differential expressed proteins.

Proteins were labelled according to the manufacturer's instructions (GE Healthcare), such that $50 \mu \mathrm{g}$ of depleted plasma proteins from NSTEACS or STEACS patients and healthy controls were labeled with $400 \mathrm{pmol}$ of N-hydroxysuccinimide Cy3 or Cy5 fluorescent cyanine dye and the labeling reaction was then quenched with $0.2 \mathrm{mM}$ lysine. All experiments included an internal standard containing equal amounts of each protein extract labeled with 400 pmol of N-hydroxysuccinimide Cy2 dye. The internal standard and two additional plasma samples (NSTEACS/STEACS and control) were combined and run on a single gel $(150 \mu \mathrm{g}$ of total protein). Protein extracts were diluted in rehydration buffer (30 mM TRIS, $7 \mathrm{M}$ Urea, $2 \mathrm{M}$ Thiourea, 4\% CHAPS) and applied to $24 \mathrm{~cm} \mathrm{pH} \mathrm{4-7} \mathrm{IPG} \mathrm{strips.} \mathrm{The}$ first dimension was run on the IPGphor IEF II System (GE Healthcare) in darkness, as follows: $500 \mathrm{~V}$ for $30 \mathrm{mi}-$ nutes, a linear gradient to $3500 \mathrm{~V}$ over $3 \mathrm{~h}, 3500 \mathrm{~V}$ for $3 \mathrm{~h}$, a linear gradient to $6000 \mathrm{~V}$ over $3 \mathrm{~h}$, and $6000 \mathrm{~V}$ until $69000 \mathrm{v} / \mathrm{h}$. After the first dimension, the strips were equilibrated in SDS-equilibration buffer $(1.5 \mathrm{M}$ Tris/HCl [pH 8.8], 6 M Urea, 87\% Glycerol and 2\% SDS).

To increase the reproducibility an electrophoresis system "Ettan DALTsix" (GE Healthcare) was used for the polymerization of the gels. To run the second dimension $10 \%$ acrylamide gels were used. To do this, $1.5 \mathrm{M}$ Tris$\mathrm{HCl} \mathrm{pH} 8.8$ was used, 10\% SDS (w/v) and milliQ water were used to obtain the desired concentration of acrylamide. APS and TEMED (BioRad) were also added to catalyst the polymerization reaction. After preparing the gels, each IPG strip was placed horizontally on the top of the gel, avoiding bubbles to remain trapped between the strip and the surface of the gel. Electrophoresis took place at $25^{\circ} \mathrm{C}$, firstly applying $5 \mathrm{~W} /$ gel for $20 \mathrm{~min}$ and then $1 \mathrm{~W} /$ gel overnight in the presence of running buffer (25 mM Tris, 0.2 M glycine, $3 \mathrm{mM} \mathrm{SDS}$ ).

\section{Image acquisition and analysis}

After SDS-PAGE, the gels were scanned on a Typhoon TRIO fluorescence gel scanner (GE Healthcare) using appropriate individual excitation and emission wavelengths, filters and photomultiplier values sensitive for each of the Cy3, Cy5 and Cy2 dyes.

Relative protein quantification was performed on NSTEACS and STEACS patients and healthy control samples using DeCyder software v6.5 (GE Healthcare) and the multivariate statistical Extended Data Analysis (EDA) module. The DIA module simultaneously detected the 3 images of each gel (the internal standard plus two samples), measured the spot abundance in each image, and expressed these values as $\mathrm{Cy} 3 / \mathrm{Cy} 2$ and $\mathrm{Cy} 5 /$ $\mathrm{Cy} 2$ ratios. These DIA datasets were then analysed using the Biological Variation Analysis (BVA) module, which matched the spot maps and compared the Cy3/Cy2 and $\mathrm{Cy} 5 / \mathrm{Cy} 2$ ratios. Differences in protein abundance $>1.5$ fold were considered significant. Statistical analysis using Student's $t$-test was performed to detect changes in protein expression, with $\mathrm{p} \leq 0.05$ accepted as significant.

Finally, a multivariate analysis was performed through a Principal Component Analysis (PCA) using the algorithm included in the EDA module of DeCyder software based on the spots that matched across all gels.

\section{Conventional two-dimensional electrophoresis (2-DE)}

For the protein spots identification 2-DE gels were used. Plasma samples were diluted in rehydration buffer and 
applied to pH 4-7 IPG strips, which were subsequently equilibrated as previously described [32,38,39]. For the second-dimension separation, 10\% SDS-PAGE was performed according to Laemmli [40] using a Protean II system (BioRad) at $4^{\circ} \mathrm{C}$ and $25 \mathrm{~mA} /$ gel. The gels were fixed overnight and Silver Stained (GE Healthcare) following the manufacturer's instructions and finally scanned with a GS-800 Calibrated Densitometer (BioRad).

\section{Protein identification by MALDI-TOF/TOF and database searching}

Protein spots from 2-DE gels were excised manually, automatically digested with an Ettan Digester (GE Healthcare) and identified at the Proteomic Unit of Hospital Nacional de Paraplejicos. In-gel trypsin digestion was performed according to Schevchenko et al. [41] with minor modifications. Peptides were extracted with $60 \%$ acetonitrile (ACN) in 0.1\% formic acid (99.5\% purity; Sigma Aldrich). Samples were dried in a speed vac and re-suspended in $98 \%$ water with $0.1 \%$ formic acid (FA) and $2 \%$ ACN. An aliquot of each digestion was mixed with an aliquot of the matrix solution (3 mg/mL matrix $\alpha$-cyano-4-Hydroxycinnamic acid: CHCA, Sigma Aldrich) in 30\% ACN, 15\% 2propanol and $0.1 \%$ TFA, and this was pipetted directly onto the stainless steel sample plate of a 384 Opti-TOF $123 \times 81 \mathrm{~mm}$ MALDI mass spectrometer (ABsciex) and dried at room temperature. MALDI-MS/MS data were obtained using an automated analysis loop in a 4800 Plus MALDI TOF/TOF Analyzer (ABsciex).

MALDI-MS and MS/MS data were combined using GPS Explorer Software Version 3.6 to search a nonredundant protein database (Swissprot 56.5) with the Mascot software version 2.2 (Matrix Science) applying the following settings: $50 \mathrm{ppm}$ precursor tolerance, 0.6 Da MS/MS fragment tolerance, 1 missed cleavage allowed, carbamidomethylcysteines (variable) and methionine oxidation (fixed) as modifications. The MALDI-MS/MS spectra and database search results were manually inspected in detail using the previous software.

\section{Pathways analysis}

Functional classification and protein interactions were investigated using publicy available bioinformatics tools: Database for Annotation, Visualisation and Integrated Discovery (DAVID v6.7) and Search Tool for the Retrieval of Interacting Genes/Proteins (STRING v9.1). DAVID bioinformatics provides an integrated biological knowledgebase and analytic tools aimed at systematically extracting biological meaning from large gene/protein lists derived from high-throughput experiments. STRING is a database and web resource dedicated to protein-protein interactions, including both physical and functional interactions, that maps all interaction evidence onto a common set of genomes and proteins. Proteins with different expression between IS patients and control were uploaded to DAVID and STRING for functional and protein interaction analyses, respectively.

\section{Western blot}

For the validation process, independent groups of samples from healthy controls and NSTEACS or STEACS patients were used. All samples were depleted and quantitated using the Bradford-Lowry method [37]. Onedimensional (1D) and two-dimensional (2D) western blots were used.

$20 \mathrm{ug}$ of protein from every depleted plasma sample were mixed with loading buffer (10\% SDS, $87 \%$ glycerol, 2-mercaptoethanol 5\% Bromophenol blue and $0.002 \%$ Tris $-\mathrm{HCl} 0.5 \mathrm{M} \mathrm{pH} \mathrm{6.8)} \mathrm{and} \mathrm{heated} \mathrm{at} 95^{\circ} \mathrm{C}$ for $5 \mathrm{~min}$ before application on the gel wells.

Then, electrophoresis was performed using SDS-PAGE different percentages of acrylamide/bisacrylamide (between 8 and $12 \%$ acrylamide), depending on the expected molecular mass of the protein to be analyzed.

Table 4 Resume of primary and secondary antibodies used for western blot validation along with dilutions and incubation times

\begin{tabular}{|c|c|c|c|c|c|c|}
\hline Protein & Primary antibody & Dilution & Incubation & Secondary antibody & Dilution & Incubation \\
\hline Gamma fibrinogen & Abcam & $1: 20000$ & 1 hour & - & - & - \\
\hline Hemopexin (NSTEACS) & Abcam & $1: 2000$ & 1 hour & Rabbit True blood eBioscience & $1: 1000$ & $45 \min$ \\
\hline Apolipoprotein E & Abcam & $1: 500$ & 1 hour & IgG antigoat donkey HRP Abcam & $1: 2000$ & $45 \min$ \\
\hline Antithrombin III (NSTEACS) & Abcam & $1: 2000$ & 1 hour & Mouse True blood eBioscience & $1: 1000$ & $45 \mathrm{~min}$ \\
\hline Alpha-1 antichymotrypsin & Abcam & $1: 2000$ & 1 hour & Mouse True blood eBioscience & $1: 1000$ & $45 \min$ \\
\hline Apolipoprotein Al & Polyclonal & $1: 50000$ & 1 hour & Rabbit True blood eBioscience & $1: 10000$ & $45 \min$ \\
\hline Coagulation Factor XII & Abcam & $1: 1000$ & 1 hour & Rabbit True blood eBioscience & $1: 10000$ & $45 \min$ \\
\hline Antithrombin III (STEACS) & Abcam & $1: 2000$ & 1 hour & Mouse True blood eBioscience & $1: 1000$ & $45 \mathrm{~min}$ \\
\hline Hemopexin (STEACS) & Abcam & $1: 200$ & 1 hour & Rabbit True blood eBioscience & $1: 10000$ & $45 \min$ \\
\hline Kallistatin & Abcam & $1: 2000$ & 1 hour & Rabbit True blood eBioscience & 1:10000 & $45 \mathrm{~min}$ \\
\hline
\end{tabular}


Protein electrophoresis in denaturing conditions was performed as described by Laemmli protocol [40] and immobilization was carried out onto nitrocellulose membranes (BioRad) by semi-dry transfer (BioRad) for $30 \mathrm{~min}$ at $20 \mathrm{~V}$, using transfer buffer $(25 \mathrm{mM}$ Tris, $151.8 \mathrm{mM}$ glycine and $20 \%$ methanol $\mathrm{v} / \mathrm{v})$. Then, the nitrocellulose membranes were stained by immersing them in a solution of Ponceau Red S (Sigma) in 0.2\% trichloroacetic acid 30\% (w/v) sulfosalicylic acid and 30\% $(\mathrm{w} / \mathrm{v})$ for $1 \mathrm{~min}$, washed with distilled water to remove excess dye and a scanned with the densitometer (GS-800 Calibrated Densitometer, BioRad). To check the performance of the transfer gels were stained with Coomassie blue. Once the proteins immobilized on nitrocellulose membranes, these were blocked in a solution of skimmed milk powder $7.5 \%(\mathrm{w} / \mathrm{v})$ in PBS/ $0.1 \%$ Tween 20 overnight at $4^{\circ} \mathrm{C}$ under stirring. After blocking, all subsequent steps were performed at room temperature and under stirring. The membranes washed three times for $10 \mathrm{~min}$ with washing buffer PBS/ 0.1\% Tween20. The membranes were incubated for 1 hour with the specific primary antibody diluted in PBS/0.1\% Tween20 (Table 4). After making three washes of $10 \mathrm{~min}$ in wash buffer, the membranes were incubated for 45 min with the appropriate secondary antibody diluted in PBS/ 0.1\% Tween20. Finally, repeated three washes of $10 \mathrm{~min}$ and revealed using the method based chemiluminescent oxidation of luminol by the action of hydrogen peroxide catalyzed by horseradish peroxidase (ECL Western Blotting Detection Reagents, GE Healthcare). Computer-assisted densitometric image analysis of digital subtraction images was performed to quantify the proteins. Student's $t$-test $(\mathrm{p}<0.05)$ was used for the statistical analysis of data.

\section{Selected reaction monitoring}

Crude plasma samples were reduced, digested and cleaned with Pep-Clean spin columns (Pierce) according to the manufacturer's instructions prior to mass spectrometry (MS) analysis in the LC-MS/MS system. It consisted of a TEMPO nano LC system (Applied Biosystems) combined with a nano LC Autosampler coupled to a modified triple quadrupole (4000 QTRAP LC/MS/MS, Applied Biosystems). Theoretical SRM transitions were designed using MRMpilot software v1.1 (ABSciex). An independent group of 15 controls and 15 NSTEACS or STEACS patients were analyzed in the 4000QTrap using a MIDAS acquisition method that included the theoretical transitions.

\section{Statistical analysis}

A Kolmogorov-Smirnov test demonstrated the normal distribution of the population analyzed. A Levene test for homogeneity of variance was performed and the Student $t$-test was used to compare band intensities. SRM statistical analysis was carried out using the GraphPad
Prism 4.0 software package and for all tests statistical significance was accepted when $\mathrm{p}<0.05$.

\section{Abbreviations}

2D-DIGE: Two-dimensional difference in gel electrophoresis; 2DE: Twodimensional electrophoresis; ACN: Acetonitrile; ACS: Acute coronary syndrome; AHA: American heart association; ApoA-I: Apolipoprotein A-l; ApoA-IV: Apolipoprotein A-IV; ApoE: Apolipoprotein E; ApoH: Apolipoprotein H; APS: Ammonium Persulfate; AS: Aortic stenosis; BVA: Biological variation analysis; CK: Creatine kinase; CKMB: Heart type creatine kinase isoenzyme; DIA: Differential in-gel analysis; EDA: Extended data analysis; ESC: European society of cardiology; HPLC: High performance liquid chromatography; MALDI: Matrix-assisted laser desorption/ionization; NSTEACS: non ST-elevation acute coronary syndrome; PCA: Principal component analysis; ROS: Reactive oxygen species; SRM: Selected reaction monitoring; STEACS: ST-elevation acute coronary syndrome; TEMED: Tetramethylethylenediamine; TOF: Time of flight; VDBP: Vitamin D-binding protein.

\section{Competing interests}

All authors declare that there are no competing interests.

\section{Authors' contributions}

CML and SA carried out the proteomic studies, the western-blot and SRM validations and drafted the manuscript. CML and LM carried out the statistical analysis and drafted the manuscript. JM, FV, LRP and MGB conceived of the study and participated in its design and coordination and helped to draft the manuscript. All authors read and approved the final manuscript.

\section{Acknowledgments}

We thank the Proteomics Unit of the HNP for assistance with the protein identification, and Carmen Bermudez and Ana Gallardo for her technical support. This work was supported by grants from the Instituto de Salud Carlos III (FIS PI070537, PI11-02239), Fondo de Investigación Sanitaria de Castilla la Mancha (FISCAM, PI2008/08) and Redes Temáticas de Investigación Cooperativa (FONDOS FEDER, RD06/0014/1015, RD12/0042/0071). These results are lined up with the Spanish initiative on the Human Proteome Project (SpHPP).

\section{Author details}

'Laboratory of Vascular Physiopathology, Hospital Nacional de Parapléjicos, SESCAM, Toledo, Spain. ${ }^{2}$ Department of Hemodynamic, Hospital Virgen de la Salud, SESCAM, Toledo, Spain. ${ }^{3}$ Department of Immunology, IIS-Fundación Jiménez Diaz, Madrid, Spain. ${ }^{4}$ Department of Biochemistry and Molecular Biology I, Universidad Complutense, Madrid, Spain. ${ }^{5}$ Department of Cardiology, Hospital Virgen de la Salud, Toledo, Spain.

Received: 1 April 2014 Accepted: 29 June 2014 Published: 10 October 2014

\section{References}

1. Murray CJ, Lopez A: Mortality by cause for eight regions of the world: global burden of disease study. Lancet 1997, 349:1269-1276.

2. Naghavi M, Libby P, Falk E, Casscells SW, Litovsky S, Rumberger J, Badimon JJ, Stefanadis C, Moreno P, Pasterkamp G, Fayad Z, Stone PH, Waxman S, Raggi P, Madjid M, Zarrabi A, Burke A, Yuan C, Fitzgerald PJ, Siscovick DS, de Korte CL, Aikawa M, Juhani Airaksinen KE, Assmann G, Becker CR, Chesebro $\mathrm{JH}$, Farb A, Galis ZS, Jackson C, Jang IK, et al: From vulnerable plaque to vulnerable patient. A call for new definitions and risk assessment strategies: part I. Circulation 2003, 108:1664-1672.

3. Libby P: Inflammation in atherosclerosis. Nature 2002, 420:868-874

4. Ross R: Atherosclerosis: an inflammatory disease. N Engl J Med 1999, 340:115-126.

5. Cosansu K, CH Ikitimur B, Yildirim E, Can G, Karadag B, Koldas L: Apelin in ST segment elevation and non-ST segment elevation acute coronary syndromes: a novel finding. Kardiol Pol 2013, 72:239-245.

6. De Hoog VC, Timmers L, Schoneveld AH, Wang JW, Van de Weg SM, Sze SK, Van Keulen JK, Hoes AW, Den Ruijter HM, De Kleijn DP, Mosterd A: Serum extracellular vesicle protein levels are associated with acute coronary syndrome. Eur Heart J Acute Cardiovasc Care 2013, 2(1):53-60.

7. Deddens JC, Colijn JM, Oerlemans MI, Pasterkamp G, Chamuleau SA, Doevendans PA, Sluijter JP: Circulating MicroRNAs as Novel Biomarkers for 
the Early Diagnosis of Acute Coronary Syndrome. J Cardiovasc Trans/ Res 2013, 6:884-898.

8. Eggers KM, Armstrong PW, Califf RM, Johnston N, Simoons ML, Venge P, James SK: Clinical and prognostic implications of circulating pentraxin 3 levels in non ST-elevation acute coronary syndrome. Clin Biochem 2013, 46:1655-1659.

9. Lincoff AM, Tardif JC, Neal B, Nicholls SJ, Rydén L, Schwartz GG, Malmberg K, Buse JB, Henry RR, Wedel H, Weichert A, Cannata R, Grobbee DE: Evaluation of the dual peroxisome proliferator-activated receptor $a / \gamma$ agonist aleglitazar to reduce cardiovascular events in patients with acute coronary syndrome and type 2 diabetes mellitus: rationale and design of the AleCardio trial. Am Heart J 2013, 166(3):429-434.

10. Raposeiras-Roubín S, Rodiño-Janeiro BK, Paradela-Dobarro B, GrigorianShamagian L, García-Acuña JM, Aguiar-Souto P, Jacquet-Hervet M, ReinoMaceiras MV, González-Juanatey JR, Alvarez E: Fluorescent advanced glycation end products and their soluble receptor: the birth of new plasmatic biomarkers for risk stratification of acute coronary syndrome. PLOS ONE 2013, 8(9):e74302.

11. The Joint European Society of Cardiology/American College of Cardiology Committee: Myocardial infarction redefined-a consensus document of The Joint European Society of Cardiology/American College of Cardiology Committee for the redefinition of myocardial infarction. Eur Heart J 2000, 21(18):1502-1513.

12. Kida D, YM Miyaura S, Ishimaru T, Yoshida $Y$, Ito $T$, Ishiguro $N$, Iwata $H$, Kimata K: The SHAP-HA complex in sera from patients with rheumatoid arthritis and osteoarthritis. J Rheumatol 1999, 26:1230-1238.

13. Yingsung $W$, Zhuo $L$, Morgelin $M$, Yoneda $M$, Kida $T$, Watanabe $H$, Ishiguro $\mathrm{N}$, Iwata $\mathrm{H}$, Kimata K: Molecular heterogeneity of the SHAP-hyaluronan complex. Isolation and characterization of the complex in synovial fluid from patients with rheumatoid arthritis. J Biol Chem 2003, 278:32710-32718.

14. Rhee SG, Woo HA, Kil IS, Bae SH: Peroxiredoxin functions as a peroxidase and a regulator and sensor of local peroxides. J Biol Chem 2012, 287(7):4403-4410.

15. Lee TH, Kim SU, Yu SL, Kim SH, Park DS, Moon HB, Dho SH, Kwon KS, Kwon HJ, Han YH, Jeong S, Kang SW, Shin HS, Lee KK, Rhee SG, Yu DY: Peroxiredoxin II is essential for sustaining life span of erythrocytes in mice. Blood 2003, 101(12):5033-5038.

16. Miller $\mathrm{YI}$, Smith A, Morgan WT, Shaklai N: Role of hemopexin in protection of low-density lipoprotein against hemoglobin-induced oxidation. Biochemistry 1996, 35(40):13112-13117.

17. Miller Yl, Altamentova SM, Shaklai N: Oxidation of low-density lipoprotein by hemoglobin stems from a heme-initiated globin radical: antioxidant role of haptoglobin. Biochemistry 1997, 36(40):12189-12198.

18. Grinshtein N, Bamm W, Tsemakhovich VA, Shaklai N: Mechanism of lowdensity lipoprotein oxidation by hemoglobin-derived iron. Biochemistry 2003, 42(23):6977-6985.

19. Twomey PJ, Viljoen A, House IM, Reynolds TM, Wierzbicki AS: Relationship between serum copper, ceruloplasmin, and non-ceruloplasmin-bound copper in routine clinical practice. Clin Chem 2005, 51(8):1558-1559.

20. Chao J, Stallone JN, Liang YM, Chen LM, Wang DZ, Chao L: Kallistatin is a potent new vasodilator. J Clin Invest 1997, 100:11-17.

21. Miao RQ, Agata J, Chao L, Chao J: Kallistatin is a new inhibitor of angiogenesis and tumor growth. Blood 2002, 100:3245-3252.

22. Wang CR, Chen SY, Wu CL, Liu MF, Jin YT, Chao L, Chao J: Prophylactic adenovirus-mediated human kallistatin gene therapy suppresses rat arthritis by inhibiting angiogenesis and inflammation. Arthritis Rheum 2005, 52:1319-1324

23. Steinmetz A, Barbaras R, Ghalim N, Clavey V, Fruchart JC, Ailhaud G: Human apolipoprotein A-IV binds to apolipoprotein A-I/A-II receptor sites and promotes cholesterol efflux from adipose cells. J Biol Chem 1990, 265:7859-7863.

24. Paszty C, Maeda N, Verstuyft J, Rubin EM: Apolipoprotein Al transgene corrects apolipoprotein E deficiency-induced atherosclerosis in mice. J Clin Invest 1994, 94:899-903.

25. Plump AS, Scott CJ, Breslow JL: Human apolipoprotein A-I gene expression increases high density lipoprotein and suppresses atherosclerosis in the apolipoprotein E- deficient mouse. Proc Natl Acad Sci U S A 1994, 91:9607-9611.

26. Ostos MA, Conconi M, Vergnes L, Baroukh N, Ribalta J, Girona J, Caillaud JM, Ochoa A, Zakin MM: Antioxidative and antiatherosclerotic effects of human apolipoprotein A-IV in apolipoprotein E-deficient mice. Arterioscler Thromb Vasc Biol 2001, 21:1023-1028.

27. Smith JD: Apolipoprotein A-I and its mimetics for the treatment of atherosclerosis. Curr Opin Investig Drugs 2010, 11(9):989-996.

28. Colman RW, Schmaier AH: Contact system: a vascular biology modulator with anticoagulant, profibrinolytic, antiadhesive and proinflammatory attributes. Blood 1997, 90:3819-3843.

29. Isordia-Salas I, Sainz IM, Pixley RA, Martinez-Murillo C, Colman RW: High molecular weight kininogen in inflammation and angiogenesis: a review of its properties and therapeutic applications. Rev Invest Clin 2005, 57:802-813.

30. Asakura S, Hurley RW, Skorstengaard K, Ohkubo I, Mosher DF: Inhibition of cell adhesion by high molecular weight kininogen. J Cell Biol 1992, 116:465-476.

31. Chavakis T, Boeckel N, Santoso S, Voss R, Isordia-Salas I, Pixley RA, Morgenstern E, Colman RW, Preissner KT: Inhibition of platelet adhesion and aggregation by a defined region (Gly-486- Lys-502) of high molecular weight kininogen. J Biol Chem 2002, 227:23157-64

32. Gil-Dones F, Darde VM, Alonso-Orgaz S, Lopez-Almodovar LF, MourinoAlvarez L, Padial LR, Vivanco F, Barderas MG: Inside human aortic stenosis: a proteomic analysis of plasma. J Proteomics 2012, 75(5):1639-53.

33. Alvarez-Llamas G, Martin-Rojas T, de la Cuesta F, Calvo E, Gil-Dones F, Dardé VM, Lopez-Almodovar LF, Padial LA, Lopez JA, Vivanco F, Barderas MG: Modification of the secretion pattern of proteases, inflammatory mediators, and extracellular matrix proteins by Human Aortic Valve is Key in Severe Aortic Stenosis. Mol Cell Proteomics 2013, 12(9):2426-2439.

34. de la Cuesta F, Barderas MG, Calvo E, Zubiri I, Maroto AS, Darde VM, MartinRojas T, Gil-Dones F, Posada-Ayala M, Tejerina T, Lopez JA, Vivanco F Alvarez-Llamas G: Secretome analysis of atherosclerotic and nonatherosclerotic arteries reveals dynamic extracellular remodeling during pathogenesis. J Proteome 2012, 75(10):2960-2971.

35. Dardé VM, de la Cuesta F, Dones FG, Alvarez-Llamas G, Barderas MG, Vivanco $\mathrm{F}$ : Analysis of the plasma proteome associated with acute coronary syndrome: does a permanent protein signature exist in the plasma of ACS patients? J Proteome Res 2010, 9(9):4420-32

36. Gil-Dones F, Darde VM, Vivanco F, Barderas MG: A comparative study of immunodepletion and equalization methods for aortic stenosis human plasma. Methods Mol Biol 2013, 1005(1005):245-56.

37. Bradford MM: A rapid and sensitive method for the quantitation of microgram quantities of protein utilizing the principle of protein-dye binding. Anal Biochem 1976, 72:248-54.

38. Gorg A, Weiss W, Dunn MJ: Current two-dimensional electrophoresis technology for proteomics. Proteomics 2004, 4:3665-85.

39. Martín-Rojas T, Gil-Dones F, Lopez-Almodovar LF, Padial LR, Vivanco F, Barderas MG: Proteomic profile of human aortic stenosis: insights into the degenerative process. J Proteome Res 2012, 11(3):1537-1550.

40. Laemmli UK: Cleavage of structural proteins during the assembly of the head of bacteriophage. Nature 1970, 227:680-5.

41. Schevchenko A, Wilm M, Vorm O, Mann M: Mass spectrometric sequencing of proteins from silver stained polyacrylamide gels. Anal Chem 1996, 68:850-8.

doi:10.1186/1477-5956-12-43

Cite this article as: Laborde et al.: The plasma proteomic signature as a strategic tool for early diagnosis of acute coronary syndrome. Proteome Science 2014 12:43.

\section{Submit your next manuscript to BioMed Central and take full advantage of:}

- Convenient online submission

- Thorough peer review

- No space constraints or color figure charges

- Immediate publication on acceptance

- Inclusion in PubMed, CAS, Scopus and Google Scholar

- Research which is freely available for redistribution 